\author{
F. M. Raimondo, A. Scialabba, R. Guarino \& R. E. Spallino
}

\title{
Genetic diversity in Sicilian populations of Quercus ilex (Fagaceae)
}

\begin{abstract}
Raimondo, F. M., Scialabba, A., Guarino, R. \& Spallino, R. E.: Genetic diversity in Sicilian populations of Quercus ilex (Fagaceae). - Fl. Medit. 23: 245-253. 2013. — ISSN: 1120-4052 printed, 2240-4538 online.

Recent studies on the genetic structure of the Italian populations of Quercus ilex demonstrated their high diversity, particularly in the Sicilian metapopulation. In order to check if the holm oak stands in the mountains of NW Sicily could have some relationship with $Q$. ilex subsp. ballota (distributed in Spain and NW Africa), 26 specimens from the Sicilian most distinctive $Q$. ilex populations have been compared with some representative populations of the Italian Peninsula, North Africa and Spain, by means of the ISSR technique. Even if the results are too preliminary to confirm or reject the initial hypothesis, they confirmed an high level of genetic variability, well distributed among the analyzed specimens. In particular, the metapopulations from the Sicilian mountains (Quacella, Vallone Canna) revealed some genetic affinity with those of the Moroccan mountains (Marrakech/Oukaimeden and Ifrane). These populations, on their turn, resulted to be quite distant from the sample from SE-Spain (Sierra de Javalambre). Moreover, a certain genetic distance has been detected from the comparison of the mountain populations of Sicily with those of coastal sites of this Island (Scopello, Castellammare) and Capri (Villa Jovis).
\end{abstract}

Key words: Quercus, ISSR analysis, genetic variability.

\section{Introduction}

Quercus ilex L. (Fagaceae) is among the most representative Mediterranean species, perhaps the one which best outlines and symbolizes the features of the Mediterranean climate and landscape. The distribution range of this oak is of bioclimatic and biogeographic significance, because on the one hand it identifies the potential range of the Mediterranean evergreen forest; on the other, it delimits the Mediterranean phytogeographic region (Quézel 1985; Guarino 2001).

This species exhibits a remarkable phenotypic variability throughout its distribution range (Fig.1), in part already noted by taxonomists and then denounced at the infraspecific level. Besides of the nominal subspecies and some local varieties, the subsp. ballota (Desf.) Samp. [= Q. rotundifolia (Lam. ) T. Morais] has been recently re-appraised, whose range extends over the most western part of the distribution area of the species, i.e. the 
Raimondo \& al.: Genetic diversity in Sicilian populations of Quercus ilex ...

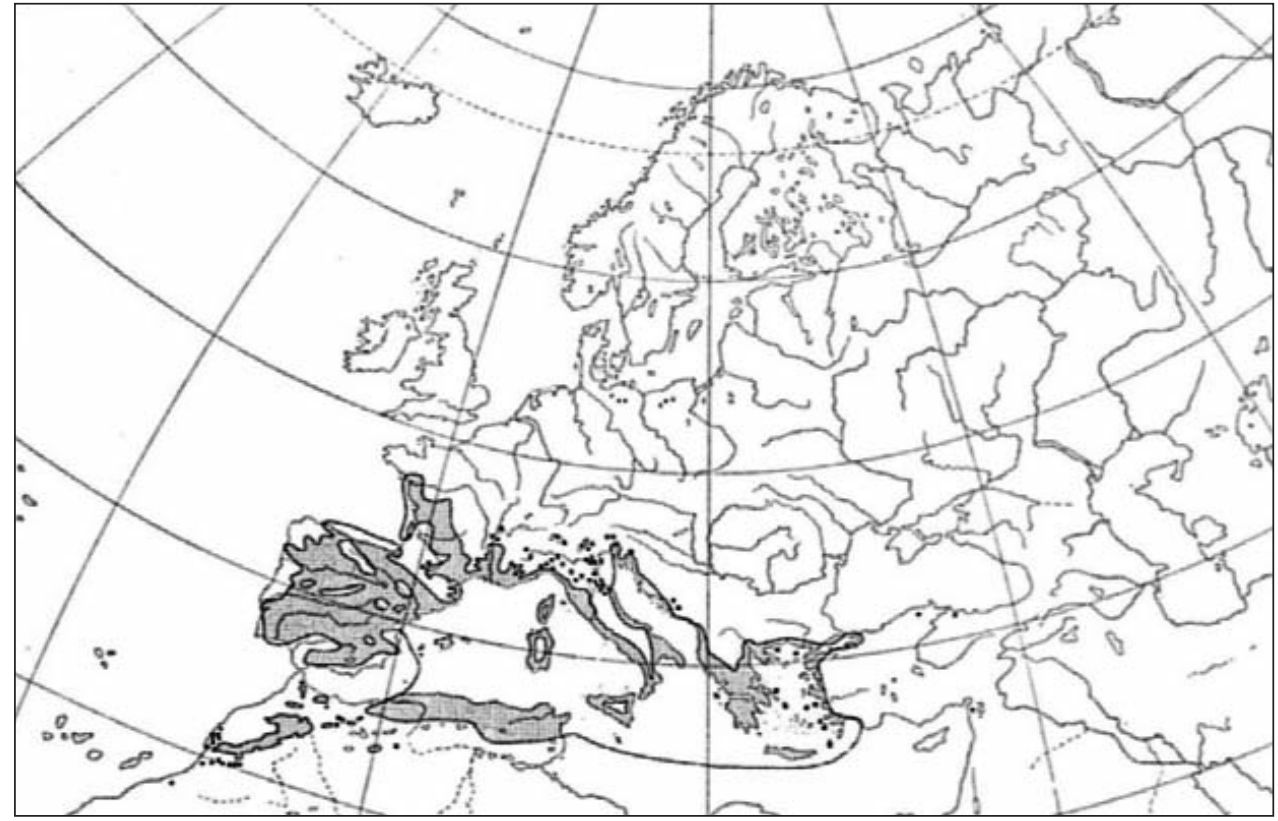

Fig. 1. Distribution of Quercus ilex L. s.l. (from Meusel \& al. 1965).

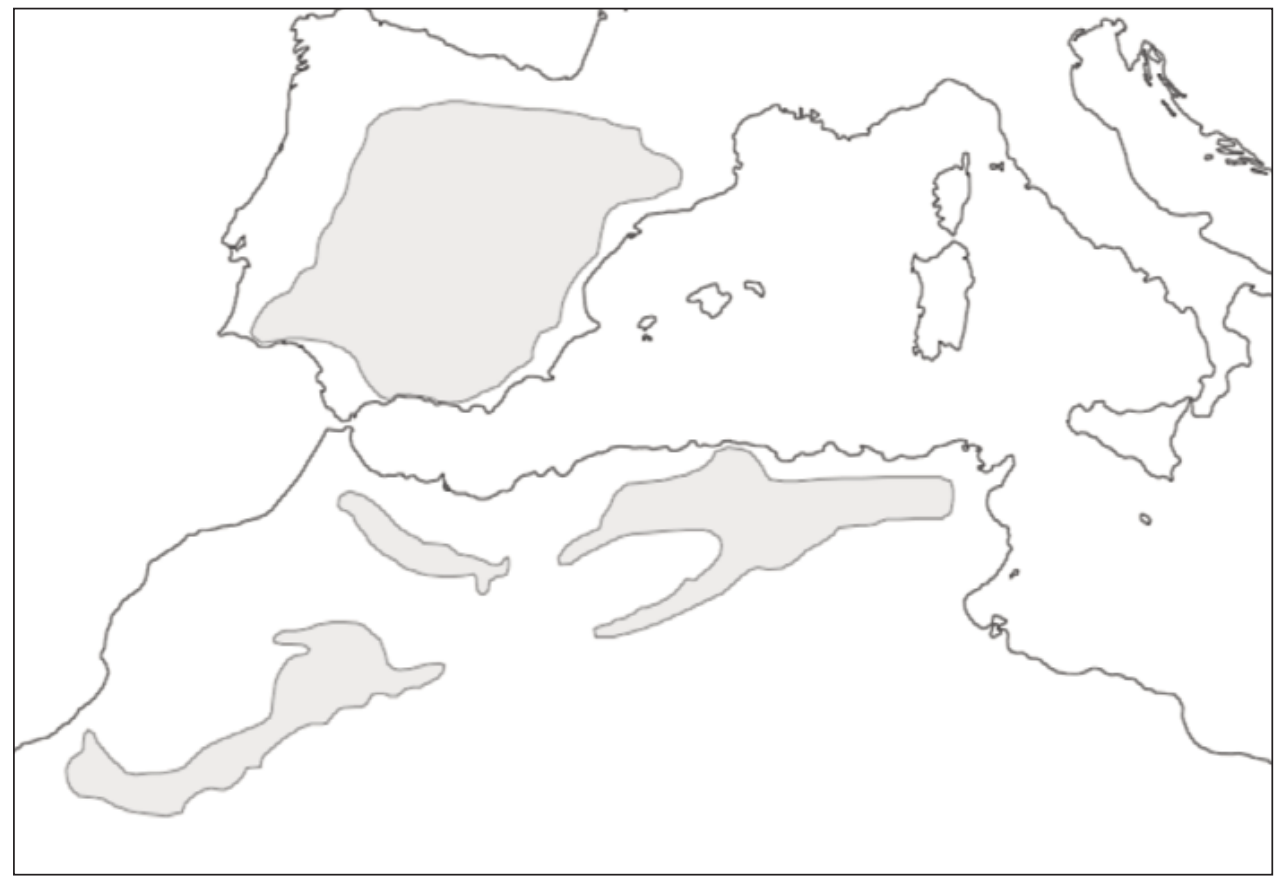

Fig. 2. Distribution of Quercus ilex subsp. ballota (Desf.) Samp. (adapted from Hiaddaden \& al. 2013). 
Iberian Peninsula and North-West Africa (Schwarz 1993; Amaral Franco 1990; Fennane \& Ibn Tattou 2005) (Fig. 2).

Recent studies on the genetic structure of the Italian populations of $Q$. ilex, demonstrated their high variability, which turned out to be particularly accentuated in the Sicilian metapopulation (Fineschi \& al. 2005).

The morphologic variability and ecological plasticity of the holm-oak in Sicily could be given by possible contacts/exchanges between the North African and the Sicilian populations and, in particular, as the result of hybridisation processes - partially followed by introgression - occurred between populations of $Q$. ilex subsp. ballota and $Q$. ilex subsp. ilex. Another plausible hypothesis would be a palaeogeographic inclusion of the most ancient districts of Sicily into the distribution range of $Q$. ilex subsp. ballota (Fig. 3 ), whose populations would then have been retained on the top of some mountain ranges of Sicily, and particularly on the carbonate summits of Madonie Mts, where it survived until present days.

To test this hypothesis, a molecular investigation has been carried out, through the comparison of the Sicilian most distinctive $Q$. ilex populations with some representative populations of the Italian Peninsula, North Africa and Spain. The results are presented in this paper.

\section{Materials and methods}

\section{Sampling}

This study is based on 26 samples collected in different times of the year 2013, from distinctive metapopulations of $Q$. ilex in central-western Sicily: Quacella Mt., south facing slopes (1450 m a.s.1 - Madonie); Quacella Mt., north facing slopes (1300 m a.s.1 - Madonie); Vallone Canna (1450 m a.s.1. - Madonie); Pomieri (1400 m a.s.1. Madonie); Gonato (1200 m a.s.1. - Madonie), Castelbuono/Barraca (750 m a.s.1. Madonie); Carrara (450 m a.s.1. - Madonie); Pollina (400 m a.s.l. - Madonie); Mt. Cammarata (900 m a.s.1. - Sicani Mts.); Corleone (730 m a.s.1. - Sicani Mts.); Ficuzza (700 m a.s.1. - Sicani Mts.); Piazza Armerina (500 m a.s.1.); Castellammare (300 m a.s.1.); Scopello (200 m a.s.1..); Montagna Grande (836 m a.s.1. - Pantelleria). Additional specimens from non-Sicilian populations were sampled from: Gennargentu Massif (1400 m a.s.1. - Sardinia); Capri Island, near Villa Jovis (354 m a.s.1. - Italy); Ifrane (1600 m a.s.1. - Morocco); between Marrakech and Oukaimeden (1200, two sites + one site at $500 \mathrm{~m}$ a.s.1. - Morocco); Sierra de Javalambre (850 m a.s.1. - Spain).

\section{DNA extraction}

The total genomic DNA was extracted from a 1 square $\mathrm{cm}$ of fresh leaf, dried in silica gel, by means of the NucleoSpin Plant II Kit (Macherey-Nagel). The concentration and quality of the extracted nucleic acids was measured by means of a spectrophotometer UV-Visible Nanodrop 2000, before being subjected to PCR analysis. DNA samples were deposited at the DNA Bank of the Herbarium Mediterraneum Panormitanum (Greuter \& al. 2012), voucher specimens are housed in PAL. 


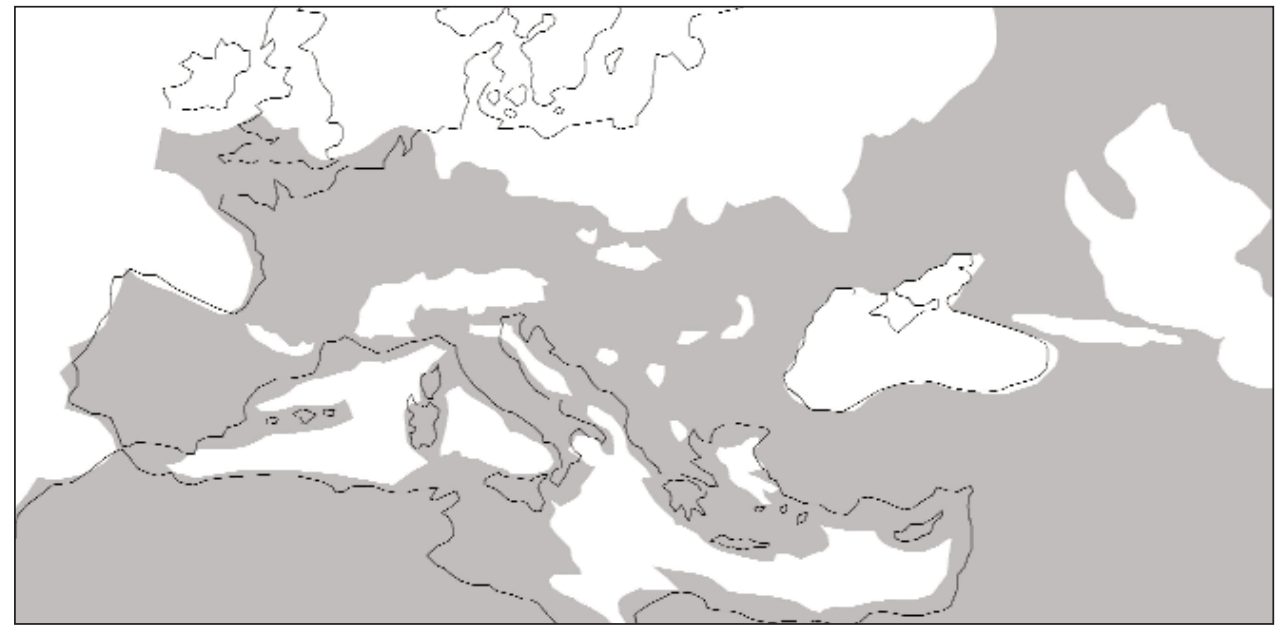

Fig. 3. The paleogeographical reconstruction of the penultimate glacial period in the Mediterranean region (redrawn from La Greca 1959).

\section{PCR Reaction}

Part of the extracted DNA was used for in vitro amplifications with primer microsatellites. The multilocus marker Inter Simple Sequence Repeats (ISSR) (Table 1) were chosen on a multi-criteria basis: clarity, number and reproducibility of the amplified fragments (Bornet \& Branchard 2004).

The reactions were performed in a volume of $25 \mu$ l of reaction mixture containing: 12.5 $\mu \mathrm{l}$ of PCR Master Mix 2X, $1 \mu \mathrm{l}$ of the above mentioned primers $10 \mu \mathrm{M}$ and one microliter of DNA as reaction target. The PCR reactions were performed with the thermocycler Applied Biosystem 2720, under the following conditions: one cycle of initial denaturation at $94^{\circ} \mathrm{C}$ ( 3 minutes), 29 cycles at $94^{\circ} \mathrm{C}$ (30 seconds each), at $52^{\circ} \mathrm{C}$ (45 seconds), at $72^{\circ}$ $\mathrm{C}\left(2\right.$ minutes) and a final cycle for the extension of DNA strands at $72^{\circ} \mathrm{C}$ for 7 minutes.

The PCR products were separated by electrophoresis in 3\% agarose gel in TBE 1X buffer (Sambrook \& al. 1989).

For electrophoretic analysis, 25-30 $\mu \mathrm{l}$ of PCR product with $2.5 \mu \mathrm{l}$ of tracer (Nucleic Acid Sample Loading Buffer, 5X - Bio-Rad) were used.

Table 1. ISSR primer sequences used in PCR analysis.

\begin{tabular}{|c|c|c|}
\hline Primer Code & Sequence $\left(5^{I} \rightarrow 3^{I}\right)$ & Reference \\
\hline UBC835 & $5^{1}-\mathrm{AGA}$ GAG AGA GAG AGA GYC $-3^{1}$ & López-Aljorna \& al. 2007 \\
\hline UBC841 & $5^{1}-$ GAG AGA GAG AGA GAG AYC $-3^{1}$ & López-Aljorna \& al. 2007 \\
\hline UBC857 & $5^{1}-\mathrm{ACA} C A C \mathrm{ACA} C A C \mathrm{ACA} C \mathrm{CYG}-3^{1}$ & López-Aljorna \& al. 2007 \\
\hline UBC878 & $5^{1}-$ GGA TGG ATG GAT GGA $T-3^{1}$ & López-Aljorna \& al. 2007 \\
\hline
\end{tabular}


The amplicons were visualized by staining with SYBR $^{\circledR}$ Safe ${ }^{\mathrm{TM}}$ DNA Gel Stain (Invitrogen), illuminated with transmitted UV radiation $(360 \mathrm{~nm})$ and images were digitalized in a transilluminator ChemiDoc ${ }^{\mathrm{TM}}$ EQ (Bio-Rad Laboratories). The molecular dimension of the amplification band was estimated by comparing the relative electrophoretic mobility with respect to the bands of known size of the markers $100 \mathrm{bp}$ - EZ Load 100 bp PCR Molecular Ruler and Precision Molecular Mass Bio-Rad (Bio-Rad )

Primer Code Sequence $\left(\mathbf{5}^{\mathbf{I}} \rightarrow \mathbf{3}^{\mathbf{I}}\right)$ Reference UBC835 $5^{\mathrm{I}}$ - AGA GAG AGA GAG AGA GYC - 3 ${ }^{\mathrm{I}}$ López-Aljorna \& al. 2007 UBC841 5 I $^{\mathrm{I}}$ GAG AGA GAG AGA GAG AYC - 3 ${ }^{\mathrm{I}}$ López-Aljorna \& al. 2007 UBC857 5 - ACA CAC ACA CAC ACA CYG - 3 ${ }^{\mathrm{I}}$ López-Aljorna \& al. 2007 UBC878 5 - GGA TGG ATG GAT GGA T - 3 López-Aljorna \& al. 2007.

\section{Results}

The ISSR technique, originally developed by Zietkiewicz \& al. (1994), makes use of semiarbitrary markers amplified by PCR in the presence of one primer complementary to a target microsatellite. Thanks to the high number of polymorphic loci that can be obtained (Dow \& Ashley 1996; Jianming \& al. 2006), the technique has been widely adopted for genome fingerprinting in many plant families (Bornet \& Branchard 2001).

In our study case, by means of 4 primers, the ISSR-PCR amplifications generated a total of 38 reliable amplicons (Fig. 4). The size of these fragments ranged between 160 and $2000 \mathrm{bp}$.

ISSR bands were interpreted as dominant markers and fragments were scored as present (1) and absent (0). A similarity matrix was calculated by means of the Dice coefficient (Dice, 1945) and a cluster diagram was obtained by means of the JMP software-10 (Fig. 5)

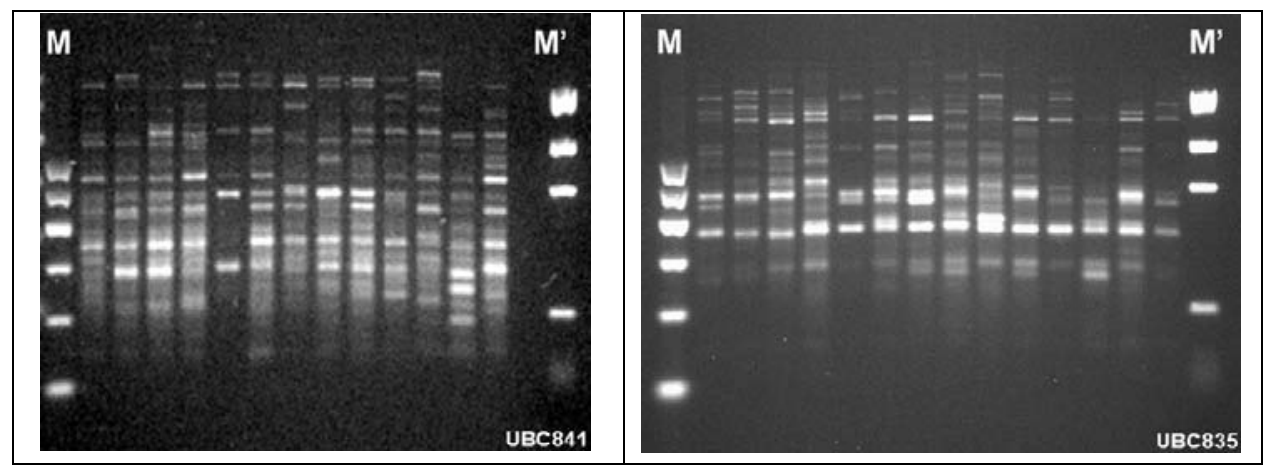

Fig. 4. Examples of ISSR patterns obtained on a $2 \%$ agarose gel for different individuals of $Q$. ilex s.l. using the primer UBC841 and UBC835. $\mathrm{M}=$ molecular size marker 100-base Ladder QIAGEN; $\mathrm{M}^{\prime}=$ Precision Molecular Mass BIO-RAD. 


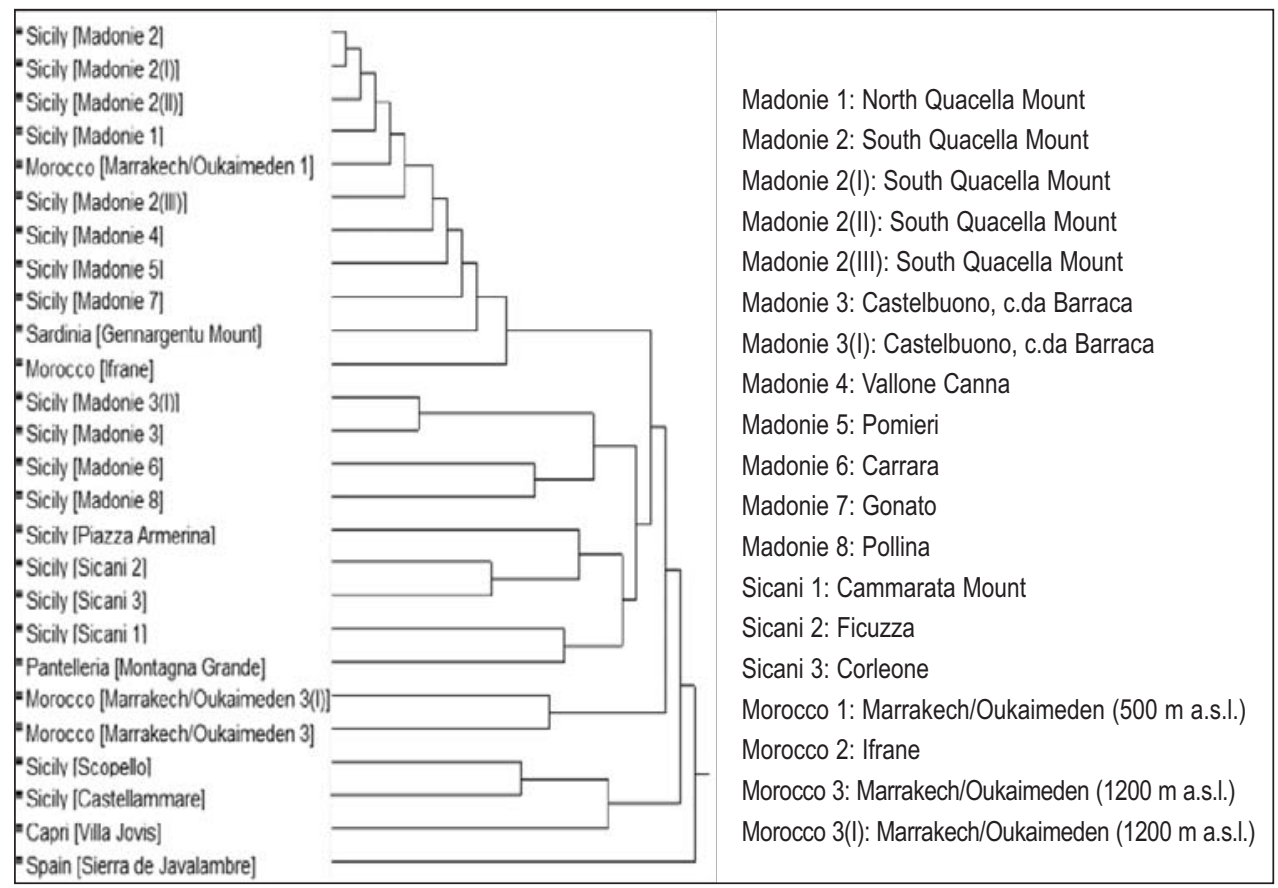

Fig. 5. Dendrogram generated by UPGMA clustering analysis, using Dice's coefficient based on 38 ISSR bands, showing the relationship among the 26 different analyzed specimens of $Q$. ilex.

The dendrogram highlights an high level of genetic variability well distributed among the analyzed specimens. The comparison of the metapopulations from the Sicilian mountains (Madonie: Quacella and Vallone Canna) with those of Sardinian mountains and Morocco (Marrakech/Oukaimeden 1 and Ifrane, referred to Q. ilex subsp. ballota) revealed some genetic affinity. These populations are in turn quite distant from the sample from SESpain (Sierra de Javalambre) also referred to Q. ilex subsp. ballota. Moreover, a certain genetic distance has been detected from the comparison of the mountain populations of Sicily with those of coastal sites of the same Island (Scopello and Castellammare) and of the Tyrrhenian island of Capri (Villa Jovis) referred to Q. ilex subsp. ilex.

\section{Conclusions}

Our preliminary results did not confirmed the hypothesis that the holm oak metapopulations of Sicilian heights may be regarded as a different taxon than $Q$. ilex subsp. ilex, perhaps closer if not equal to $Q$. ilex subsp. ballota. However, further analyses are required, basing on more samples, to firmly reject this hypothesis. Still it is a fact that, on the Madonie Mts., holm oak forests are in contact with the beechwoods, at an elevation (over $1750 \mathrm{~m}$ above sea level) (Figs. 6-8) which is rather unusual in the context of the distribution area of Quercus ilex s. s. 


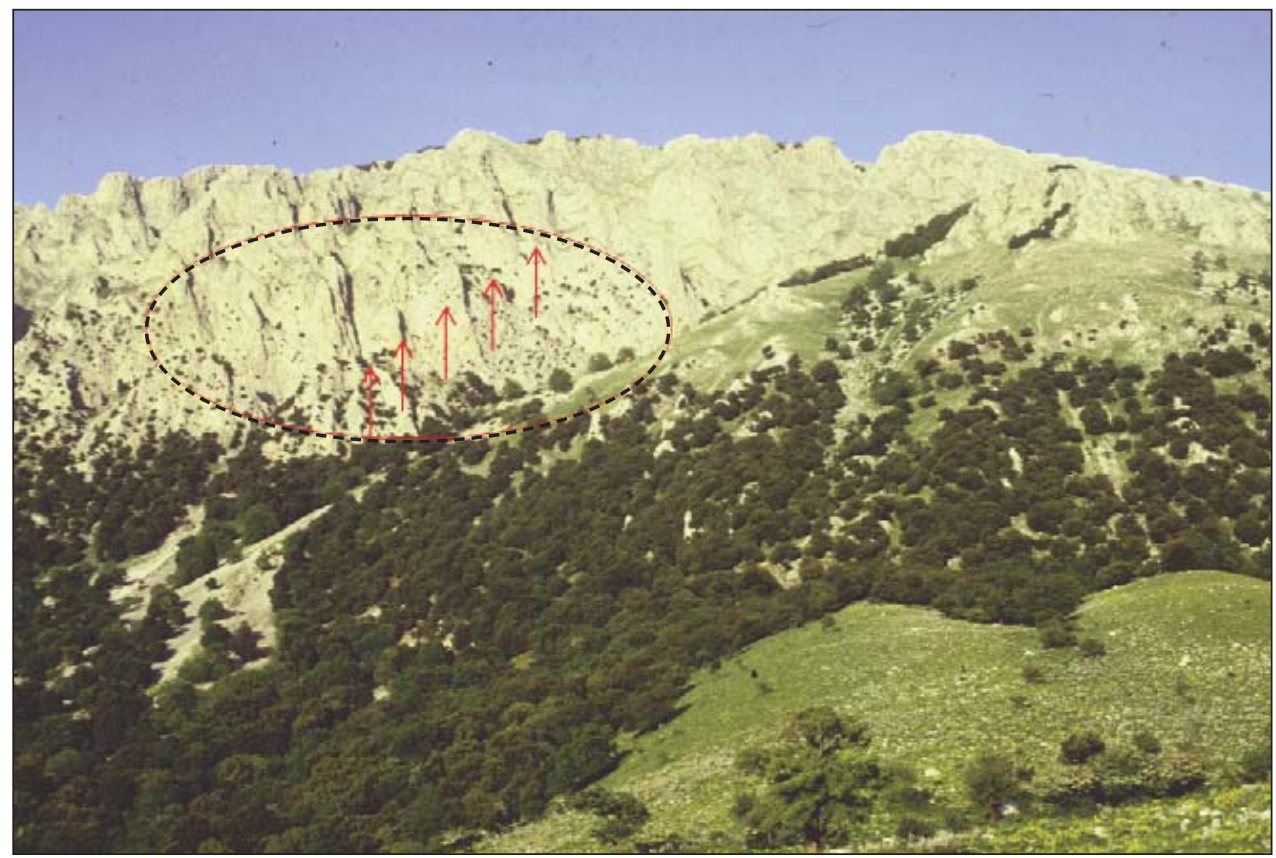

Fig. 6. Quercus ilex occurrence from the bottom to the top of the Madonie mountains (West Carbonara Mount, $1850 \mathrm{~m}$ a.s.l.).

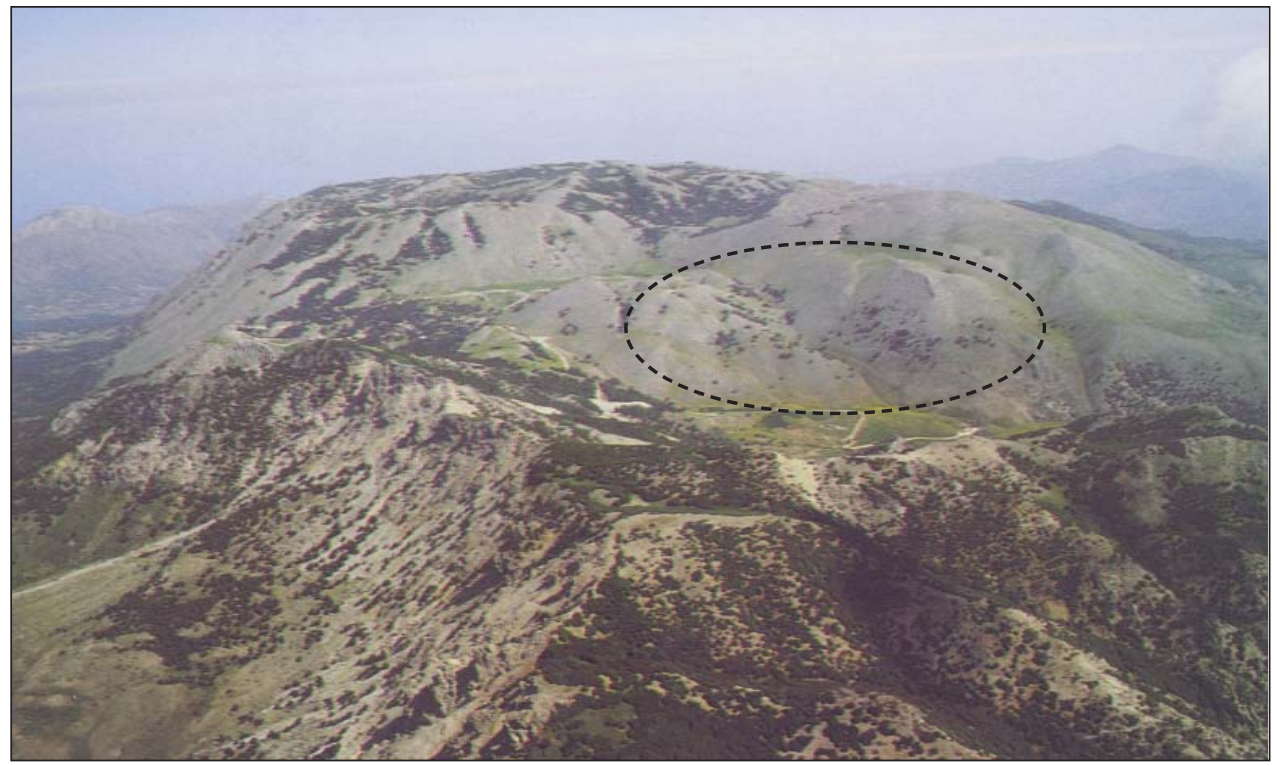

Fig. 7. Eastern slope of the Carbonara Mount (about $1750 \mathrm{~m}$ a.s.1.) with mountain populations of holm oak. 


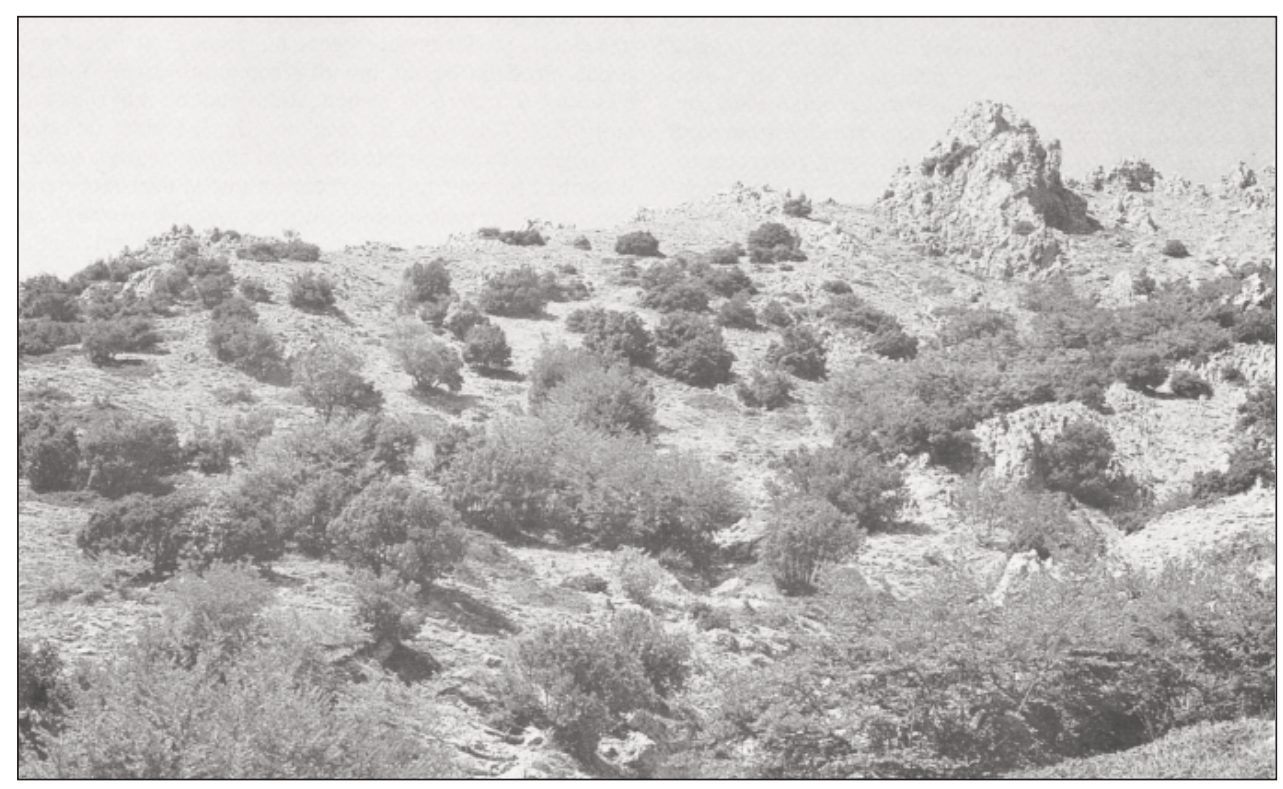

Fig. 8. Southern slope of the Quacella Mount (about 1800 m a.s.1.) where Quercus ilex and Fagus sylvatica communities come into direct contact.

Moreover, morphometric and ecological analysis conducted on the population of the Madonie mountains reveal divergent features from the nominal subspecies and closer to $Q$. ilex subsp. ballota. Quite interestingly an ethnobiologic investigation drove to similar results, since the mountain populations of holm oak are traditionally distinct by charcoal producers as "ilici muscarinu", juxtaposed to the normal holm-oak (simply named "ilici") because of its harder and much durable wood (Raimondo 2013; Raimondo \& al. 2013).

In conclusion, this seems to be an interesting case study, worth to be further and thoroughly analysed, with the aim to achieve a better characterization of the genomic and morphologic features of such critical Sicilian populations.

\section{Acknowledgements}

Consorzio Universitario della Provincia di Palermo, International Foundation pro Herbario Mediterraneo and University of Palermo (Fondi di Ateneo per la ricerca) are gratefully acknowledged.

\section{References}

Amaral Franco (do), J. 1990: Quercus L. - Pp.15-36 in: Castroviejo, S., Laìnz, M., Lopez González, G., Montserrat, P., Muñoz Garmendia, F., Paiva, J., Villar, L., Flora Iberica, 2. - Madrid.

Bornet, B., Brancard, M. 2001: Nonanchored inter simple sequence repeat (ISSR) markers: reproducible and specific tools for genome fingerprinting. - Pl. Mol. Biol. Rep. 19: 209-215.

Dice, L. R. 1945: Measures of the amount of ecologic association between species. - Ecology 26: 297-302. 
Dow, B. D., Ashley, M. V. 1996: High levels of gene flow in bur oak revealed by paternity analysis using microsatellites. - J. Hered. 89: 62-70.

Fennane, M., Ibn Tattou, M. 2005: Flore vasculaire du Marroc, inventaire et chorologie 1. - Trav. Inst. Sci., Sér. Bot., 37. - Rabat.

Fineschi, S., Cozzolino, S., Migliaccio, M., Musacchio, A., Innocenti, M., Vendramin, G.G. 2005: Sicily represents the Italian reservoir of chloroplast DNA diversity of Quercus ilex L. (Fagaceae). - Ann. Forest. Sci. 62: 79-84.

Greuter, W., Raimondo, F. M., Scialabba, A., Spallino, R. E. 2012: Una banca del DNA della flora della regione mediterranea. - P. 71 in: $107^{\circ}$ Congresso della Società Botanica Italiana Onlus, Riassunti. - Dragoni, Caserta.

Guarino, R. 2001: Proposta per una parametrizzazione dei fattori stazionali nell'indice di Mitrakos. - Ecol. Medit. 27(1): 33-54.

Ihaddaden, A., Velazquez, E., Rey-Benayas, J.M., Kadi-Hanifi, H., 2013: Climate and vegetation structure determine plant diversity in Quercus ilex woodlands along an aridity and human-use gradient in Northern Algeria. - Flora 208(4): 268-284.

La Greca, M., 1959: La Fauna. In: Conosci l'Italia, IV. -Milano.

López-Aljorna, A., Bueno, M. A., Aguinagalde, I., Martin, J. P. 2007: Fingerprinting and genetic variability in cork oak (Quercus suber L.) elite trees using ISSR and SSR markers. - Ann. For. Sci. 64: 773-779. doi: 10.1051/forest:2007057

Quézel, P., 1985: Definition of the Mediterranean region and origin of its flora. - Pp. 9-24 in: Gomez-Campo, C. (ed.), Plant conservation in the Mediterranean Area. - Geobotany, 7. Lancaster.

Raimondo, F. M., Guarino, R., Scialabba, A., Spallino, R. E. 2013: Genetic diversity in Sicilian populations of Quercus ilex (Fagaceae). - P. 138 in Domina, G., Greuter, W. G. \& Raimondo, F. N., XIV OPTIMA Meeting, book of abstracts. - Palermo.

— 2013: Biodiversità nella dendroflora italiana. - Italia Forest. Mont. 68(5): 233-257.

Sambrook, J., Fritsh, E. F., Maniatis, T. 1989: Molecular cloning: A laboratory Manual. -New York. Schwarz, O. 1993: Quercus L. - Pp. $72-76$ in: Tutin, T. G., Burges, N. A., Chater, A. O., Edmondson, J. R., Heywood, V. H., Moore, D. M., Valentine, D. H., Walters, S. M., Webb, D. A., Flora Europaea, 1 ( $\left.2^{\text {nd }} E d.\right)$. - Cambridge.

Zietkiewicz, E., Rafalski, A., Labuda, D. 1994: Genome fingerprinting by simple sequence repeat (SSR)-achored polymerase chain reaction amplification. - Genomics 20: 176-183.

Address of the authors:

Francesco M. Raimondo, Anna Scialabba, Riccardo Guarino \& Rosa Elena Spallino, Università di Palermo, Dip. STEBICEF/Sezione di Botanica ed Ecologia vegetale Laboratorio Sistema Madonie (Castelbuono), via Archirafi 38. - 90123 Palermo.

Italy. E-mail: francesco.raimondo@unipa.it 
